\title{
Durability and Strength Properties of Geopolymer Mortar Reinforced with Natural Fibre
}

\author{
Abishek $^{1}$, Dr. Hemant Sood ${ }^{2}$ \\ M.E. Student ${ }^{1}$, Department of Civil Engineering ${ }^{1}$, NITTTR Chandigarh ${ }^{1}$ \\ Professor $^{2}$, Department of Civil Engineering ${ }^{2}$, NITTTR Chandigarh ${ }^{2}$ \\ Email:abishek16thakur@gmail.com ${ }^{l}$
}

\begin{abstract}
The study in this paper is to eliminate the amount of cement from concrete or mortar by complete replacement of cement with geopolymer. Geopolymer is a binding material produced from the reaction of low calcium fly ash with alkaline activator solution. The activator solutions are combination of sodium hydroxide $(\mathrm{NaOH})$ and sodium silicate $\left(\mathrm{Na}_{2} \mathrm{SiO}_{3}\right)$. Systematic trials were carried to optimize the ratio of sodium silicate to sodium hydroxide in activator solution. This paper investigates the strength property of plain geopolymer mortar and geopolymer mortar reinforced with natural fibre for different percentages $0.1 \%$ to $0.5 \%$ by the weight of fly ash. The mortar cubes were tested at the curing ages of 3, 7 and 28days. The results of indicated that $0.4 \%$ was the optimum fibre content in fibre reinforced geopolymer mortar. Water absorption test was performed for durability study on fibre reinforced geopolymer mortar after 28 days curing period. It is also observed that compressive strength of GPM increases on addition of natural fibre (shel) from $0.1 \%$ to $0.4 \%$ and achieved maximum compressive strength $42.10 \mathrm{~N} / \mathrm{mm} 2$ (28 days) at $0.4 \%$.
\end{abstract}

Keywords-Geopolymer, Class-F, Natural Fibre, Alkaline Activator, Water Absorption

\section{INTRODUCTION}

The increased emphasis on sustainable development and environmental protection has lead to examination of alternatives to conventional building materials. The process of Portland cement manufacturing requires large amount of energy and produces a large volume of carbon dioxide $\left(\mathrm{CO}_{2}\right)$ to the atmosphere. The lowcalcium fly ash is used with sand in place of cement along with alkaline liquid to produce geo-polymer mortar. In 1978, J. Davidovits suggested that an alkaline liquid could be used to react with low-calcium fly ash that contains $\mathrm{Si}$ and $\mathrm{Al}$ to produce geo-cement. This geo-cement is formed by polymerization process. To make alkaline liquids sodium silicate and sodium hydroxide or potassium hydroxide and potassium silicate may be used.

J. Davidovits later in 1994, introduced the term 'Geopolymer' to represent these geo-cement. In geopolymer mortar or concrete the strength is depends on various factors such as types of source material, fineness of sand, chemical composition of fly ash, types of activator solution, ratio of solution to binder, $\mathrm{Na} 2 \mathrm{SiO} 3$ to $\mathrm{NaOH}$, curing temperature, types of curing and concentration of $\mathrm{NaOH}$ solution. Geopolymer concrete gains popularity globally towards the sustainable development. Low-calcium fly ash and alkaline liquid is used to produce binder which binds the aggregate. It is a new technology that minimizes $\mathrm{CO} 2$ production into the environment. The main constituents in low-calcium fly ash those would be activated are $\mathrm{Si}$ and $\mathrm{Al}$. The low-calcium fly ash mixed with alkaline liquid and the binder is produced by polymerization. Sand obtained from the crusher plant, stone dust, natural sand and river sand is generally used as a fine aggregate in mortar, which is becoming insufficient and costly due to the transportation charges from their sources. Due to depletion of these sources many environmental problems are created.

\section{LITERATURE REVIEW}

Major Davidovits Joseph (2002) in this paper attempt is made to study environmentally driven geopolymer applications based on the implementation of (K,Ca)-Poly(sialate-siloxo) / (K,Ca)-Poly(sialatedisiloxo) cements. Geopolymeric cement generates six times less $\mathrm{CO}_{2}$ during manufacture than Portland cement. Immobilization technologies with geopolymeric materials have three goals. First one is to seal the hazardous materials into an impermeable monolith. This prevents the direct contact of potential leachates, like ground water and percolating rain. Geopolymeric cements do not rely on lime and are not dissolved by acidic solutions. Portland based cements (plain and slag mixtureed) are destroyed in acidic environment.

Hardjito Djwantoro et.al. (2004) in this paper efforts were made to develop environmentally friendly construction materials. To reduce greenhouse gas emissions, fly ash based geopolymer concrete was developed. In geopolymer concrete, low-calcium fly ash was chemically activated by a high-alkaline solution to form a paste that binds the loose coarse and fine aggregates together. The manufacture of geopolymer concrete is carried out using the usual concrete technology methods. Higher curing temperature resulted in larger compressive strength, even though an increase in the curing temperature beyond $60^{\circ} \mathrm{C}$ did not increase the compressive strength substantially. To evaluate the resistance of geopolymer concrete to sulphate attack, specimens were soaked in a $5 \%$ sodium sulphate $\left(\mathrm{Na}_{2} \mathrm{SO}_{4}\right)$ 
International Journal of Research in Advent Technology, Vol.7, No.3, March 2019

E-ISSN: 2321-9637

\section{Available online at www.ijrat.org}

solution for different periods of time. The author concluded that higher concentration (in terms of molar) of sodium hydroxide solution results in a higher compressive strength. Higher the ratio of sodium silicate-to-sodium hydroxide liquid ratio by mass, higher is the compressive strength.

Wallah Edward Steenie (2009) in this paper attempt is made to study the drying shrinkage of heat-cured fly ash-based geopolymer concrete. As a relatively new material, extensive studies are still needed to explore this type of concrete as a construction material. One area that needs to be studied is its shrinkage behaviour, which is an important long-term property of concrete. Shrinkage is the decrease in volume of concrete with time. Unlike creep, shrinkage is independent of the external factors to the concrete. There are some types of shrinkage in the concrete which should be distinguished - plastic shrinkage, chemical shrinkage, thermal shrinkage and drying shrinkage. The aggregates play a significant role in affecting the shrinkage of concrete. This is related to the restraining effect of the aggregate on shrinkage. The higher aggregate content results in smaller shrinkage and also concrete with aggregates of higher modulus or rougher surfaces is more resistance to the shrinkage process. The author concluded that the heatcured fly ash-based geopolymer concrete undergoes very low drying shrinkage.

Lloyd N A and Rangan B V et.al. (2010) tests are conducted to identify the effects of salient factors that influence the properties of the geopolymer concrete and to propose a simple method for the design of geopolymer concrete mixtures. Studies have been carried out on fly ash-based geopolymer concrete. The compressive strength and the workability of geopolymer concrete are influenced by the proportions and properties of the constituent materials that make the geopolymer paste. Heat-curing of low-calcium fly ash-based geopolymer concrete is generally recommended. Heat-curing substantially assists the chemical reaction that occurs in the geopolymer paste. Both curing time and curing temperature influence the compressive strength of geopolymer. The results of the tests conducted on large-scale reinforced geopolymer concrete member's show that geopolymer concrete is well-suited to manufacture precast concrete products that can be used in infrastructure developments and geopolymer concrete has excellent properties.

Al Bakri Mustafa Mohd et.al. (2011) made attempt to develop environment friendly concrete by replacing OPC with fly ash. The consumption of Ordinary Portland Cement (OPC) caused pollution to the environment due to the emission of $\mathrm{CO} 2$. The compressive strength increases with the increasing of fly ash fineness and thus the reduction in porosity can be obtained. Setting time of geopolymer depend on many factors such as composition of alkaline solution and ratio of alkaline liquid to fly ash by mass. However, the curing temperature is the most important factor for geopolymer. As the curing temperature increases, the setting time of concrete is decreases. During curing process, the geopolymer concrete experience polymerization process. Due to increase in temperature, polymerization become more rapid and the concrete can gain $70 \%$ of its strength within 3 to 4 hr of curing. The author concluded that fly ash-based geopolymer is better than normal concrete in many aspects such as compressive strength, exposure to aggressive environment, workability and exposure to high temperature.

Sanni H Shankar, Khadiranaikar R B (2012) investigated the variation of alkaline solution on mechanical properties of geopolymer concrete. The grades preferred for the investigations were M30, M40, M50 and M60; the mixes were designed for 8 molar. The alkaline solution used was the combination of sodium silicate and sodium hydroxide solution with the varying ratio of 2, 2.5, 3 and 3.5.

The test specimens were $150 \times 150 \times 150 \mathrm{~mm}$ cubes and $100 \times 200 \mathrm{~mm}$ cylinders heat-cured at $60^{\circ} \mathrm{C}$ in an oven. The results revealed that the workable flow of geopolymer concrete was in the range of 85 to $145 \mathrm{~mm}$ and was dependent on the ratio by mass of sodium hydroxide and sodium silicate solution. The freshly prepared geopolymer mixes were cohesive and their workability increased with the increase in the ratio of alkaline solution. It was concluded that the strength of geopolymer concrete can be improved by decreasing the water/binding and aggregate/binding ratios. Compressive strength and split tensile strength obtained were in the range of $20.64-60 \mathrm{~N} / \mathrm{mm}^{2}$ and 3$4.9 \mathrm{~N} / \mathrm{mm}^{2}$.

Yellaiah P. et.al. (2014) investigated the influence of various parameters on the consistency and setting times of low-calcium fly ash based geopolymer cement under varied heat curing temperature were investigated. The consistency of geopolymer cement does not show any variation when mixed with different combinations of alkaline activator solution; whereas the setting times were observed to be dependent on concentration of $\mathrm{NaOH}$ solution, ratio of alkaline liquid and variation in temperature. The test results revealed that the normal consistency of geopolymer paste is found to be at $28 \%$ of alkaline activator solution for all the selected mixtures. Wherein, increase in concentration of $\mathrm{NaOH}$ solution increases setting times; increase in alkaline liquid ratio decreases setting times up to certain limits viz; increase in alkaline liquid ratio from 1.5 to 2.0 decreases setting times; further increase in alkaline liquid ratio from 2.0 to 2.5 increases setting times.

Gull Iftekar, Sofi Yasir (2015) intended to study the properties of fly ash based Geopolymer concrete. M20 grade GPC can be formed by adopting nominal mix of 1:1.5:3 (fly ash: fine aggregates: coarse aggregates) by varying alkaline liquid to fly ash ratio from 0.3 to 0.45 . The compressive strength, tensile strength and flexural strength tests were conducted on geopolymer concrete and parameters that affect it are analyzed and 


\section{Available online at www.ijrat.org}

proved experimentally. The durability properties like permeability and acid attack are also studied. From the test results, it was concluded that geopolymer concrete possesses good compressive strength and offers good durability characteristics. With the increase of alkaline liquid to fly ash ratio strength decreases and alkaline liquid to fly ash ratio less than 0.3 is very stiff.

\section{MATERIALS USED}

\subsection{Fly ash}

Fly ash considered one of the most important source materials to produce geopolymer cements. Low calcium based fly ash was used in this work which generally known as ASTM Class F. The ignition of hard, aged anthracite and bituminous coal generally produce Class F low-calcium fly ash. This lowcalcium fly ash is pozzolanic in nature, and also contains $\mathrm{CaO}$ (lime) less than $7 \%$. Having pozzolanic characteristics, the $\mathrm{Si}$ and $\mathrm{Al}$ of Class $\mathrm{F}$ low-calcium fly ash requires a binding agent, such as OPC, burnt lime or slaked lime unite to react and to form binding compounds. Adding an alkaline activator such as $\mathrm{Na} 2 \mathrm{SiO} 3$ (water glass) to Class $\mathrm{F}$ fly ash can produce a geo-cement.
3.1.1. Properties of fly ash
- Specific gravity : 2.08
- Fineness Blaine's specific surface area : $462.8 \mathrm{~m}^{2} / \mathrm{kg}$
- Soundness by autoclave : $0.27 \%$
- Drying shrinkage : $0.057 \%$

\subsection{Fine aggregate}

Fine aggregate generally includes the particles that all passes through $4.75 \mathrm{~mm}$ sieve and retain on $0.075 \mathrm{~mm}$ sieve. River sand or fine aggregate was used in this work. The grading of sand used conforms to Zone II of IS: 383-2016. According to its grading, IS specifications classify the fine aggregate into four types as fine aggregate of grading Zone-I to grading Zone-IV. The fine aggregates become progressively finer from grading Zone-I to grading Zone-IV. The sieve analysis helps to find out the zone of sand, size of aggregate and to find out particle size distribution of sand used.

\subsubsection{Properties of fine aggregate}

- Specific gravity : 2.62

- Water absorption : $1.62 \%$

- Fineness modulus : 2.57

\subsection{Natural Fibre}

Natural Fibres are fibres that are produced by plants, animals and geological processes. In this study, we used Shel which is an example of Bast fibres. Shel is generally obtained from a multipurpose tree called Bhimal (Biul or Beuhal). Common occurrence of Bhimal is in North India upto an altitude of $2000 \mathrm{~m}$. Bhimal (Grewia Optiva scientific name) is a moderate sized tree which can grow up to 45 feet and 4.5 feet in girth. Besides fruits, fuel wood and fodder the tree also yield very useful jute like fibre called Shel. The shel fibre is extracted either by biological or chemical retting processes. Biological retting process is most widely practicable. In biological process, branches or stems are cut in the month of March and kept for cold water retting in bundles which lasts for 40-50 days. After that following beating, the stem is dried for few days. Finally, the bark of stem is extracted golden coloured fibres are separated from the bark. The fibres are sun dried and stored in dry place. The fibres obtained are $1-3 \mathrm{~m}$ in length and $17-25$ microns is size. In this study, the shel fibre is cutted into smaller pieces of length $18 \mathrm{~mm}$. The shel fibre is used in varied proportions from $0.1 \%$ to $0.5 \%$ by the weight of binder.

\subsection{Alkaline activator solution}

Generally, the combination of $\mathrm{NaOH}$ or $\mathrm{KOH}$ and $\mathrm{Na}_{2} \mathrm{SO}_{3}$ or $\mathrm{K}_{2} \mathrm{SO}_{3}$ is used to make alkaline solution for polymerization. In this study, sodium hydroxide and sodium silicate are mixed together to from alkaline activator. $\mathrm{NaOH}$ pellets are dissolved in tap water to form $14 \mathrm{M}$ concentration solution. When the alkaline solution contains soluble silicate reactions occur at a high rate with low calcium fly ash, as compared to the use of alkaline hydroxides only. $\mathrm{Na}_{2} \mathrm{SO}_{3}$ solution added to the $\mathrm{NaOH}$ solution to prepare alkaline solution in SS/SH ratio 2.0. The alkaline solution is then produced by mixing both the chemical solutions together completely. There after an unspecified amount of heat is released due to the mixing $\mathrm{Na}_{2} \mathrm{SO}_{3}$ with $\mathrm{NaOH}$ solution. Therefore it is prepared 24 hours prior to use.

\section{EXPERIMENTAL WORK \\ 4.1 Compressive strength test}

Compressive strength test is the most important test for all types concretes and mortars. Low-calcium fly ash based geopolymer mortar specimens were prepared as per IS: 4031 (part-I) - 1988 standard for ordinary cement mortar by replacing water with activator solution and cement with class-F fly ash. For activator solution, the concentration of sodium hydroxide $(\mathrm{NaOH})$ solution is kept $14 \mathrm{M}$ and the ratio of $\mathrm{Na}_{2} \mathrm{SiO}_{3}$ to $\mathrm{NaOH}$ (i.e. SS/SH ratio) is kept 2.0. When $\mathrm{NaOH}$ solution was cooled then it was mixed with sodium silicate $\left(\mathrm{Na}_{2} \mathrm{SiO}_{3}\right)$ in desired concentration (i.e. SS/SH ratio 2.0) at least 24 hours prior to use. All the specimens prepared for testing strength of geopolymer mortar were casted in standard moulds of size $70.6 \mathrm{~mm} \times 70.6 \mathrm{~mm} \times 70.6 \mathrm{~mm}$ (IS: 10080). Specimens prepared then placed in hot air oven for curing at a specified temperature of $90^{\circ} \mathrm{C}$ and allowed to cure for next 24 hours. The prepared moulds then de-moulded after 24 hours and allowed to ambient curing at room temperature until testing. The specimens prepared were tested at 3,7 and 28 days for compressive strength under CTM 
International Journal of Research in Advent Technology, Vol.7, No.3, March 2019

E-ISSN: 2321-9637

\section{Available online at www.ijrat.org}

Table no.1 Compressive Strength of Geopolymer Mortar Reinforced with Shel

\begin{tabular}{|c|c|c|c|}
\hline \multirow{2}{*}{$\begin{array}{c}\text { Fibre } \\
\text { content }\end{array}$} & \multicolumn{3}{|c|}{ Compressive strength $\left(\mathbf{N} / \mathbf{m m}^{\mathbf{2}}\right)$} \\
\cline { 2 - 4 } & 3 days & 7 days & 28 days \\
\hline $0.1 \%$ & 27.69 & 30.89 & 36.11 \\
\hline $0.2 \%$ & 29.30 & 32.50 & 38.12 \\
\hline $0.3 \%$ & 31.50 & 34.31 & 39.73 \\
\hline $0.4 \%$ & 33.50 & 36.72 & 42.10 \\
\hline $0.5 \%$ & 31.90 & 34.61 & 40.02 \\
\hline
\end{tabular}

\subsection{Water absorption test}

A set of two Cubes specimen of $70.6 \mathrm{~mm} \times 70.6 \mathrm{~mm} \times$ $70.6 \mathrm{~mm}$ size were casted for each percentage of natural fibre from $0.1 \%$ to $0.5 \%$ and placed for 28 days in room temperature. After that cube were kept in oven at a temperature of $105^{\circ} \mathrm{C}$ to a constant mass for 24 hours. The cubes weight was recorded as W1. Cooled the cubes to the room temperature and immersed in water for 24 hours till the saturation weight as W2. The percentage of gain in weight of cube is water absorption shown in table 2 .

Table no. 2 water absorption of geopolymer mortar reinforced with shel

\begin{tabular}{|c|c|c|c|}
\hline $\begin{array}{c}\text { Fibre } \\
\text { content }\end{array}$ & W1 & W2 & $\begin{array}{c}\text { Water } \\
\text { absorption } \\
\text { \% }\end{array}$ \\
\hline $0.0 \%$ & 650 & 688 & 5.85 \\
\hline $0.1 \%$ & 642 & 682 & 6.23 \\
\hline $0.2 \%$ & 646 & 689 & 6.65 \\
\hline $0.3 \%$ & 636 & 681 & 7.07 \\
\hline $0.4 \%$ & 632 & 680 & 7.59 \\
\hline $0.5 \%$ & 616 & 665 & 7.95 \\
\hline
\end{tabular}

\section{RESULT AND DISCUSSION}

\subsection{Compressive strength}

A total of fifty four cubes 3 nos. in each set for different percentage of natural fibre $(0.1 \%, 0.2 \%$, $0.3 \%, 0.4 \%$ and $0.5 \%$ ) are prepared to study their effect on compressive strength of GPM reinforced with natural fibre under curing temperature of $90^{\circ} \mathrm{C}$. The figures show that compressive strength of GPM increases significantly on the addition of natural fibre (shel) in different percentage. It is indicated by graph below clearly that the compressive strength at 3, 7 and 28 days increase in the similar manner with respect to change in percentage of natural fibre. It is also observed that compressive strength of GPM increases on addition of natural fibre (shel) from $0.1 \%$ to $0.4 \%$ and achieved maximum compressive strength $42.10 \mathrm{~N} / \mathrm{mm}^{2}$ (28 days) at $0.4 \%$.

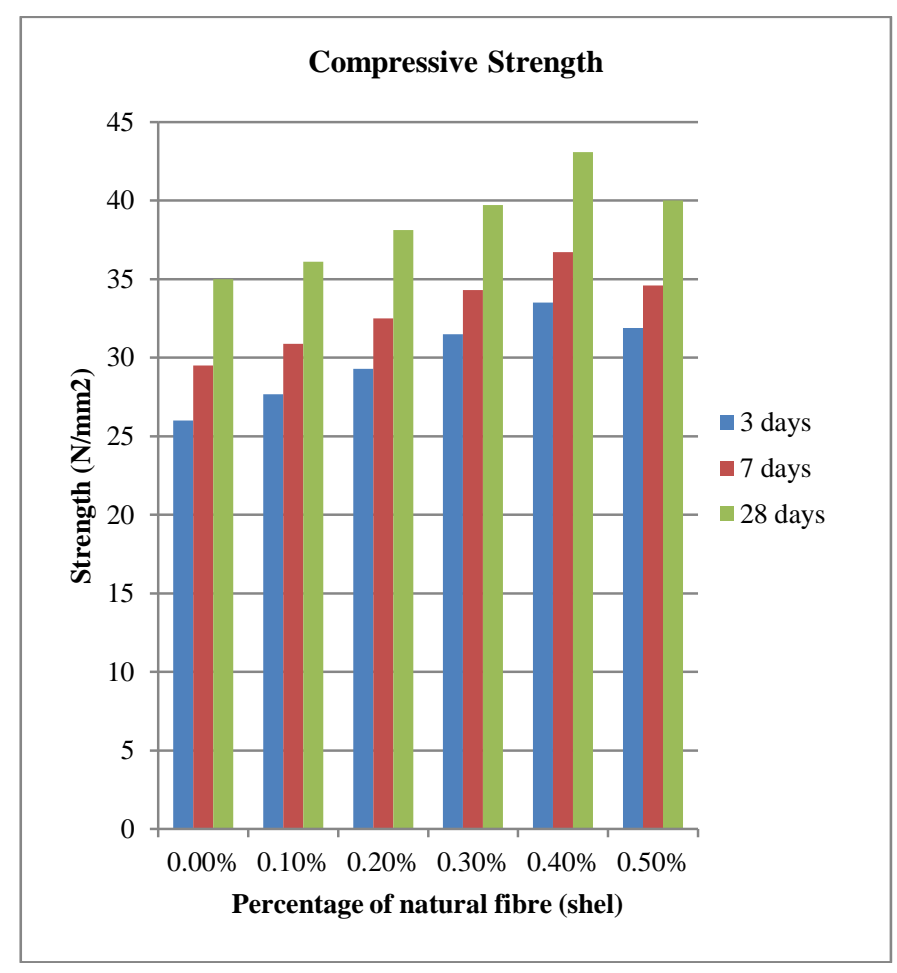

Figure 1 comparative Graphs for Compressive Strength at 3 Days, 7 Days and 28 Days

\subsection{Water absorption}

A total of 12 cubes 2 nos. in each set for different percentage of natural fibre $0.0 \%, 0.1 \%, 0.2 \%, 0.3 \%$, $0.4 \%$ and $0.5 \%$ are prepared for water absorption test on GPM reinforced with natural fibre. After 28 days ambient curing specimens prepared are tested and percentage of water absorption is as shown graph below. Water absorption percentage of fibre reinforced GPM increases as the percentage of natural fibre $(0.1$ to $0.5 \%)$ increases. 
International Journal of Research in Advent Technology, Vol.7, No.3, March 2019 E-ISSN: 2321-9637

\section{Available online at www.ijrat.org}

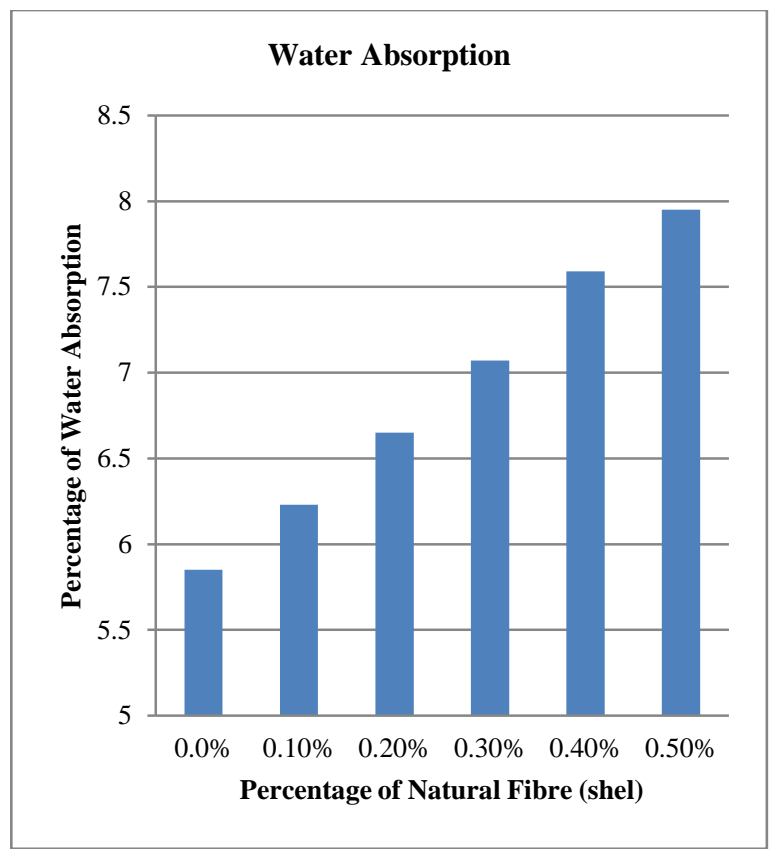

Figure 2 Graph for water absorption at 28 days

\section{CONCLUSION}

Based on the limited experimental study, the following conclusions are drawn:

- Compressive strength is found optimum at SS/SH ratio of 2.0 with $14 \mathrm{M}$ concentration of $\mathrm{NaOH}$ solution.

- At lower curing temperature higher setting time is observed and difficult to de-mould. Hence increase in curing temperature to $90^{\circ} \mathrm{C}$ decreases setting time and provide an ease in de-moulding.

- The compressive strength of GPM reinforced with natural fibre (shel) increases with increase in fibre content from $0.1 \%$ to $0.4 \%$ and then further increase in fibre content from $0.4 \%$ to $0.5 \%$ decreases the compressive strength of GPM.

- Maximum compressive strength of fibre reinforced geopolymer mortar was found $42.10 \mathrm{~N} / \mathrm{mm}^{2}$ at $0.4 \%$.

- Water absorption percentage of fibre reinforced GPM increases as the percentage of natural fibre (0.1 to $0.5 \%)$ increases.

\section{REFERENCES}

[1]Davidovits Joseph, "Properties of geopolymer cement", First international conference on alkaline cement and concrete, pp. 131-149, 1994.

[2]Davidovits Joseph, "Chemistry of geopolymeric systems terminology", Geopolymer '99 international conference, Saint-Quentin, France, 1999.

[3]Davidovits Joseph, Geopolymer institute SaintQuentin, France, "Environmentally driven geopolymer cement applications", Geopolymer conference, Melbourne, Australia, October 2002.

[4]Hardjito Djwantoro, Wallah E. Steenie, Sumajouw M. J. Dody, Rangan B.Vijaya, "Development of fly ash-based geopolymer concrete", ACI materials journal, November-December 2004.

[5]Hardjito Djwantoro, Wallah E. Steenie, Sumajouw M. J. Dody, Rangan B.Vijaya, "Factors influencing the compressive strength of fly ash-based geopolymer concrete", Civil engineering dimension, Vol. 6, issue No. 2, 2004.

[6]Hardjito Djwantoro, Wallah E. Steenie, Sumajouw M. J. Dody, Rangan B.Vijaya, "Introducing fly ash-based geopolymer concrete (manufacture and engineering properties)", 30th conference on our world in concrete \& structures, 24 August 2005.

[7]Wallah Edward Steenie, "Drying shrinkage of heatcured fly ash based geopolymer concrete", Modern applied science www.ccsenet.org/journal.html, vol3, issue-12, December 2009.

[8]Lloyd N. A, Rangan B. V, "Geopolymer concrete with fly ash", Second international conference on sustainable construction material and technologies, June 2010.

[9]Raijiwala D.B., Path H.S., "Geopolymer concrete: A green concrete", 2nd international conference on chemical, biological and environmental engineering, 2010.

[10]Al Bakri Mustafa Mohd, Mohammed H., Kamarudin H., Niza I. Khairul, Zarina Y., "Fly ash-based geopolymer concrete without Portland cement", Journal of engineering and technology research, Vol. 3(1), January 2011.

[11]Anuar K.A, Ridzuan A.R.M, Ismail S, "Strength characteristics of geopolymer concrete containing recycled concrete aggregate", International journal of civil \& environmental engineering, Vol-11, Issue-01, February 2011.

[12]Aleem M.I. Abdul, Arumairaj P.D., “Optimum mix for the geopolymer concrete", Indian journal of science and technology, Vol-5, Issue-3, March 2012.

[13]Laskar Islam Aminul, Bhattacharjee Rajan, "Effect of plasticizer and superplasticizer on workability of fly ash based geopolymer concrete", International conference on advances in architecture and civil engineering, Vol. 2, ISBN 978-93-82338, pp. 21-23, June 2012.

[14]Bhosale M.A., Shinde N.N., "Geopolymer concrete by using fly ash in construction”, IOSR journal of mechanical and civil engineering, Vol-1, Issue-3, July-August 2012.

[15]Joseph Benny, Mathew George, "Influence of aggregate content on the behavior of fly ash based geopolymer concrete" Scientia iranica, Vol. 19, Issue 5, pp. 1188-1194, October 2012. 